\title{
A COMPARATIVE ANALYSIS OF DETERMINANTS OF ISLAMIC AND CONVENTIONAL BANKING PERFORMANCES IN INDONESIA
}

\author{
${ }^{1}$ Sri Ulina, ${ }^{2, *}$ M. Shabri Abd. Majid \\ ${ }^{1,2}$ Department of Islamic Economics, \\ Faculty of Economics and Business, Universitas Syiah Kuala, \\ Darussalam, Banda Aceh, 23111 \\ *Corresponding author: mshabri@unsyiah.ac.id
}

\begin{abstract}
This study attempts to explore comparatively the determinants of financial performances between the conventional and Islamic banks in Indonesia. The determinants investigated in the study include liquidity, non-performing financing, capital adequacy, and operational cost. The samples of this study are three state-owned conventional banks and three Islamic banks that were selected by the purposive sampling technique. Based on the panel regression analysis, the study found that, for the conventional banks, capital adequacy, liquidity, and operational cost had significant influences on banks' performances, while the non-performing loan had an insignificant effect. On the other hand, for the Islamic banks, the liquidity, non-performing financing, and operational cost had significant influences on banks' performance, while capital adequacy had an insignificant effect. These findings provide important implications for the respective banks to design a proper financial policy to enhance their performances by focusing on the significant determinants affecting banks' performances.
\end{abstract}

Keywords: Banking performances, Islamic banks, Financing risk management, Capital adequacy, Operating expenses.

\section{Introduction}

In Indonesia, banking institutions consist of conventional and Islamic banks. Unlike the conventional bank that is operating based on interest principle, the practices of Islamic bank is based on Islamic tenets, which are interest-free (Kassim, Majid, \& Yusof, 2009; Majid \& Kassim, 2015). Article No. 4 of Law No. 25, the year 2018, concerning Islamic banking states that Islamic banks perform its intermediary functions in collecting and channeling funds according to Islamic principles. In its operation, Islamic banks have the vision to support national economic development people's welfare based on the principles of justice and equity.

Islamic banks are relatively new when compared with conventional banks that have existed in the early 1950s. The establishment of Islamic banks in Indonesia began with the establishment of

Received: 2020-03-08 | Reviced: 2020-05-24 | Accepted: 2020-07-02

Indexed : Sinta, DOAJ, Garuda, Crossref, Google Scholar | DOI: https://doi.org/10.29313/amwaluna.v4i2.5819 
Bank Muamalat Indonesia in 1992. Islamic banks have been experiencing promising growth in the last two decades. According to a report from the Financial Services Authority in its Sharia Banking Statistics (Otoritas Jasa Keuangan, 2016), there are 14 fullfledged Islamic banks with 1,919 offices, 20 Islamic Business Units with 381 of offices, and 164 Islamic Rural Banks with 617 offices. The increasing number of full-fledged Islamic banks was due to the conversion of Islamic bank business units into the full-fledged Islamic banks. One of the breakthroughs in the Indonesian banking industry is the conversion of local government-owned banks, namely Bank Aceh to Bank Aceh Syariah in August 2016 and Bank Nusa Tenggara Barat (NTB) in 2018, caused the number of Islamic banks in the country increased 14 banks. Thus, the number of Islamic bank assets has increased, and Islamic banks have continued to experience progress over the years.

To accomplish its intermediary financial role, the bank needs to gain the trust of the public to use its services. Amid increasing volatility of world economic conditions (Majid \& Kassim, 2009), public confidence in banking institutions has also changed. Therefore, in winning a competition with its competitors, the bank must strive to gain the trust of its customers.

Having a good performance helps the Islamic banks to win the competition from their conventional banks. The financial performance of a bank reflects the health condition of the bank. Having a good bank performance would have helped the bank maintain an excellent reputation for the bank's external parties (Betharino, 2015). Thus, a study on how to continuously improve a bank's financial performance is critical so that the bank could accomplish its functions, role, and objective. If financial performance remains good and is not adversely affected by economic fluctuations, it will regain public confidence. Financial ratios can be used to measure the financial performance of banks. This financial performance is also influenced by various factors.

Research comparing the financial performance of Islamic banks in Indonesia has been previously conducted by Winarso (2008), Pratikto \& Sugianto (2011), and Sabbina (2014). However, their studies only compared the financial performance among Islamic banks and ignored its comparison with 
conventional banks. Although there have been studies on the comparative financial performance of Islamic banks with conventional banks in developed and developing countries, such as the study conducted in Malaysia (Rosly \& Bakar, 2003; Wasiuzzaman \& Nair Gunasegavan, 2013), Pakistan (Jaffar \& Manarvi, 2011; Khan, Khan, \& Tahir, 2017), and Turkey (Erol et al., 2014) using a Capital, Asset Quality, Management, Earning, and Liquidity approaches (CAMEL) approach, but they only measured bank's performance using its average value.

Furthermore, Hazzi \& Kilani (2013) analyzed the differences in the financial performance of Islamic banks and conventional banks in Malaysia using an independent sample t-test, but the study failed to compare the bank's performance with other bank groups.

The comparative financial performance of conventional banks and Islamic banks in Indonesia has been studied by Subaweh (2008), Ardiyana (2011), Setyaningsih \& Utami (2013), Nugraha (2014), (Srisusilawati, 2017) and Betharino (2015), but their sample selection consisting of only one conventional and Islamic bank over a shorter data periods.
Finally, the studies on the analysis of the determination of financial performance have also been conducted by Sukarno \& Syaichu (2006), Aryati \& Balafif (2007), Dewi (2010), Sabir \& Habbe (2012), and Margaretha \& Zai (2013), but their studies focused on a smaller number of the banks, using shorter data periods, and generally utilizing time-series multiple linear regression analysis. Utilizing a smaller number of Islamic banks over a shorter data period and using the time-series regression analysis for panel data, the previous studies failed to provide comprehensive and robust empirical evidence of the determinants of financial performances of the conventional and Islamic banks. This is also the main weakness of the study by Majid, Musnadi, \& Putra (2014) that explored the effect of profitability, loan risk, and debt management on the quality level of asset management of Islamic banks and conventional banks in Indonesia that utilized panel data, but in the data analysis instead, they used time series multiple linear regression analysis.

Thus, this study intends to fill up the shortcomings of the previous studies by comparatively explores the determinants of conventional and Islamic banking 
performances. A larger number of Islamic and conventional banks over a more extended and recent study period are investigated using panel multiple regression analysis to arrive at more comprehensive and robust empirical evidence. Therefore, this study compares the determinants of Islamic banks' financial performance with their conventional counterparts in Indonesia during the 2003.Q1-2017.Q4 period.

The results of this study are useful for academics to provide insights on the comparative determination of the financial performance of Islamic banks and conventional banks and to be a reference for future researches. The study findings are also expected to be beneficial for both Islamic and conventional banks' management to be used as policy references to enhance their financial performance. The banks could improve what is still lacking, and can also be taken into consideration in making decisions amid increasingly fierce competition in the banking industry in Indonesia.

\section{Research Methods}

Data

This study empirically compares the determinants of Islamic banks' financial performance with conventional banks over 15 years, namely from 2003.Q1 to 2017.Q4. The data from the banks' financial statements in the form of financial ratios were utilized for the analysis. The secondary data adopted in the study were collected from several sources, namely the reports from the Financial Services Authority - FSA (www.ojk.go.id) and from the websites of each sampled bank.

This study population comprises 115 conventional commercial banks and 13 fullfledged Islamic commercial banks in Indonesia. Of these banks, the three largest state-owned banks from each conventional and Islamic bank's categories were selected as the sample of the study using the purposive sampling technique. Only the banks that meet the criterion of publishing quarterly financial statements from the period 2003.Q1 to 2017.Q4 were selected. In more detail, the sample of the study is illustrated in Table 1. 
Table 1

Sample of the study

\begin{tabular}{ccl}
\hline No. & \multicolumn{1}{c}{ Conventional Bank } & \multicolumn{1}{c}{ Islamic Bank } \\
\hline 1. & nk Rakyat Indonesia (BRI) & Bank Muamalat Indonesia (BMI) \\
2. & Bank Negara Indonesia (BNI) & Bank Syariah Mandiri (BSM) \\
3. & Bank Mandiri (BM) & Bank Mega Syariah (BMS) \\
\hline
\end{tabular}

\section{Measurement of the Variables}

In this study, four determinants of financial performances of conventional and Islamic banks are investigated, namely capital adequacy, liquidity, non-performing loans or financing, and operating costs. For more details, variables, operationalized definitions, and their measurements are explained in Table 2.

Table 2

Definitions and measurements of the variables

\begin{tabular}{|c|c|c|c|}
\hline Variable & Definition & Measurement & Scale \\
\hline \multicolumn{4}{|l|}{ Dependent: } \\
\hline $\begin{array}{l}\text { Financial } \\
\text { Performance }\end{array}$ & $\begin{array}{l}\text { An ability of a bank to produce net profit } \\
\text { using its available assets (Rose \& } \\
\text { Hudgins, 2005). }\end{array}$ & ROA $=\frac{\text { Profit after Tax }}{\text { Total Assets }} \times 100 \%$ & Ratio \\
\hline \multicolumn{4}{|l|}{$\begin{array}{l}\text { Independen } \\
\text { t: }\end{array}$} \\
\hline $\begin{array}{l}\text { Capital } \\
\text { Adequacy }\end{array}$ & $\begin{array}{l}\text { A comparison of the amount of its own } \\
\text { capital owned by banks with risk- } \\
\text { weighted assets (Kusumo, 2008). }\end{array}$ & CAR $=\frac{\text { Own Capital }}{\text { Risk Weigted Assets }} \times 100 \%$ & Ratio \\
\hline Liquidity & $\begin{array}{l}\text { An ability of a bank to meet its } \\
\text { obligations, repay all of its depositors, } \\
\text { and provide loans or financing proposed } \\
\text { by customers without delay (Hazzi \& } \\
\text { Kilani, 2013). }\end{array}$ & $\begin{array}{l}\text { LDR }=\frac{\text { Total Loans }}{\text { Total Third Party Funds }} \times 100 \% \\
\text { LDF }=\frac{\text { Total Financing }}{\text { Total Third Party Funds }} \times 100 \%\end{array}$ & Ratio \\
\hline $\begin{array}{l}\text { Non- } \\
\text { Performing } \\
\text { Loans } \\
\text { (Financing) }\end{array}$ & $\begin{array}{l}\text { An inability of customers to repay } \\
\text { loans received from banks in } \\
\text { accordance with a predetermined } \\
\text { period (Aryati \& Balafif, 2007). }\end{array}$ & $\begin{aligned} \mathrm{NPL} & =\frac{\text { Non }- \text { Performing Loans }}{\text { Total Loans }} \times 100 \% \\
\mathrm{NPF} & =\frac{\text { Non }- \text { Performing Financing }}{\text { Total Loans }} \times 100 \%\end{aligned}$ & Ratio \\
\hline $\begin{array}{l}\text { Operating } \\
\text { Expenses }\end{array}$ & $\begin{array}{l}\text { A comparison of operating costs with } \\
\text { operating income aims to measure the } \\
\text { efficiency of bank operations (Ongore \& } \\
\text { Kusa, 2013). }\end{array}$ & $\mathrm{CIR}=\frac{\text { Operating Expenses }}{\text { Operating Income }} \times 100 \%$ & Ratio \\
\hline
\end{tabular}

Note: ROA is the Return on Assets, CAR is the Capital Adequacy Ratio, LDR is the Loan to Deposit Ratio, FDR is the Financing to Deposit Ratio, NPL is the Non-Performing Loan, NPF is the Non-Performing Financing, and CIR is the Cost to Income Ratio. The term "loan" is used for conventional banks, while the term "financing" is used for an Islamic bank. 


\section{Estimated Research Model}

A comparative analysis of determinants of financial performances between conventional and Islamic banks over the period from 2003 to 2017 is estimated by regressing the financial performance of each selected Islamic and conventional banks as the dependent variable on the capital adequacy, liquidity, non-performing loans (financing), and operating costs as the independent variables. The following panel multiple regression equation will be estimated for the respected conventional banks (Equation 1) and Islamic banks (Equation 2).

$$
\begin{aligned}
& R O A_{i t}=\alpha+\beta_{1} C A R_{i t}+\beta_{2} L D R_{i t}+\beta_{3} N P L_{i t}+\beta_{4} C I R_{i t}+\varepsilon_{i t} \\
& R O A_{i t}=\alpha+\beta_{1} C A R_{i t}+\beta_{2} F D R_{i t}+\beta_{3} N P F_{i t}+\beta_{4} C I R_{i t}+\varepsilon_{i t}
\end{aligned}
$$

where $R O A$ is the ratio of return on assets to measure financial performance, $\alpha$ is an intercept, $\beta_{1}-\beta_{4}$ are the estimated coefficient, $C A R$ is the capital adequacy ratio to measure capital adequacy, $L D R$ is the loan to deposit ratio to measure liquidity for the conventional bank, $F D R$ is the financing to deposit ratio to measure liquidity for the Islamic bank, $N P L$ is the non-performing loans to measure the credit risk management for the conventional bank, NPF is the nonperforming financing to measure the financing risk management for the Islamic bank, CIR is the cost to income ratio to measure the operating costs, $i$ and $t$ indicate a particular bank at a certain year, and $\varepsilon$ is an error term.

In analyzing the panel data, three estimated models, namely the common effect model, the fixed effects model, and the random-effects model are commonly used (Hamid, Majid, \& Khairunnisah, 2017; Majid \& Maulana, 2012; Arfan et al., 2017; Yani, Arfan, \& Majid, 2020). This study will select the best-suited models for data analysis using the following tests, namely: (i) the Chow test is conducted to choose between the common- and fixed-effect models; (ii) the Lagrange Multiplier test is conducted to select between the common- and the random-effect models; and (iii) the Hausman test is performed to choose between the fixed- and random-effects models.

From the results of the tests, an appropriate model will be selected to estimate the determinants of financial performances both for Islamic and conventional banks. 


\section{Results and Discussion}

In this section, the study provides and discusses the findings of the study, comprising descriptive statistics, correlation coefficients, the estimated determinations of banks' financial performances, and the implications of the findings.

\section{Descriptive Statistics}

Descriptive statistics that are reported in Table 3 describes the maximum, minimum, mean, and standard deviation values of each variable.

Table 3

Descriptive Statistics $(\mathrm{n}=180)$

\begin{tabular}{lcccc}
\hline \multicolumn{1}{c}{ Variable } & Minimum & Maximum & Mean & Standard Deviation \\
\hline Conventional Bank: & & & & \\
Financial Performance & 1.11 & 11.84 & 4.27 & 2.18 \\
Capital Adequacy & 12.02 & 58.25 & 26.63 & 12.77 \\
Liquidity & 59.15 & 163.31 & 94.86 & 24.00 \\
Non-Performing Loan & 0.32 & 32.10 & 6.80 & 6.98 \\
Operating Expenses & 22.06 & 185.15 & 104.78 & 44.76 \\
\hline Islamic Bank: & & & & \\
Financial Performance & -1.21 & 5.97 & 1.85 & 1.24 \\
Capital Adequacy & 8.30 & 37.67 & 14.10 & 3.96 \\
Liquidity & 22.40 & 132.91 & 73.73 & 26.06 \\
Non-Performing Financing & 0.15 & 7.32 & 2.61 & 1.34 \\
Operating Expenses & 60.06 & 106.76 & 85.59 & 8.66 \\
\hline
\end{tabular}

As illustrated in Table 3, the financial performance of conventional banks was superior to that of Islamic banks. The high performance of the conventional banks was caused by their abilities to manage their assets optimally to generate profit. However, if viewed from the standard deviation, Islamic banks recorded a smaller value compared to conventional banks. This finding further shows more stability of the Islamic banks in generating profit over the study period.
Similarly, conventional banks recorded higher capital adequacy as compared to Islamic banks. The conventional banks that have been already existed more than a half-century earlier than the Islamic banks could easily generate more capital for their operations. Overall, the capital adequacy of both conventional and Islamic banks was in the ideal category, which is above $8 \%$, as stipulated by the FSA.

Judging from the average and maximum values of liquidity, the conventional banks documented higher 
liquidity than that of Islamic banks. This evidence shows that conventional banks have channeled more funds to provide credit to customers. Meanwhile, more stringent regulations for Islamic banks in channeling funds that must be following Islamic principles might lower their liquidity.

In terms of financing risk, Islamic banks are found to be superior compared to conventional banks. This is reflected by the average value of the nonperforming loan of $2.61 \%$, which is below the $5 \%$ criteria, as set by the FSA. Meanwhile, on average, the nonperforming loan of the conventional banks was $6.80 \%$, which is above the minimum criteria set the FSA, even their maximum value reached $32.10 \%$ in 2003.Q1. This shows that Islamic banks have implemented a better financing risk management by selectively channeling their financing based on the profit-loss sharing principles, thereby minimizing their financing default (Hassan AlTamimi et al., 2015).
Finally, comparing to the conventional banks, Islamic banks recorded lower operating expenses, as shown by the lower value of cost to income ratio. Thus, this shows that Islamic banks have been more efficient in their operational activities. This could be partially due to the smaller size of the banks and fewer employees than their conventional counterparts. This finding indicates that the older banks are not guaranteed to be more efficient.

\section{Correlation Coefficients}

The correlation coefficient shows the strength of the association between investigated variables. Based on Pearson correlation coefficients, as shown in Table 4, the study recorded a significant correlation between all variables at the $1 \%$ level in both conventional and Islamic banks. However, their levels of correlation varied; some of them were strongly correlated, while some others were moderately and weakly correlated. 
Table 4

Coefficient of the Pearson Correlation $(n=180)$

\begin{tabular}{|c|c|c|c|c|c|}
\hline Variable & $\begin{array}{c}\text { Financial } \\
\text { Performance }\end{array}$ & $\begin{array}{c}\text { Capital } \\
\text { Adequacy }\end{array}$ & Liquidity & $\begin{array}{l}\text { Non-Performing } \\
\text { Loan/Financing }\end{array}$ & $\begin{array}{l}\text { Operating } \\
\text { Expenses }\end{array}$ \\
\hline Conventional Bank: & & & & & \\
\hline $\begin{array}{l}\text { Financial Performance } \\
\text { Capital Adequacy }\end{array}$ & $\begin{array}{c}1 \\
0.494^{* *} \\
(0.000)\end{array}$ & 1 & & & \\
\hline Liquidity & $\begin{array}{l}0.841^{* *} \\
(0.000)\end{array}$ & $\begin{array}{l}0.529^{* *} \\
(0.000)\end{array}$ & 1 & & \\
\hline Non-Performing Loan & $\begin{array}{l}0.386^{* *} \\
(0.000)\end{array}$ & $\begin{array}{l}0.865^{* *} \\
(0.000)\end{array}$ & $\begin{array}{l}0.487^{* *} \\
(0.000)\end{array}$ & 1 & \\
\hline Operating Expenses & $\begin{array}{l}0.540^{* *} \\
(0.000)\end{array}$ & $\begin{array}{l}0.872^{* *} \\
(0.000)\end{array}$ & $\begin{array}{l}0.669^{* *} \\
(0.000)\end{array}$ & $\begin{array}{l}0.866^{* *} \\
(0.000)\end{array}$ & 1 \\
\hline Islamic Bank: & & & & & \\
\hline $\begin{array}{l}\text { Financial Performance } \\
\text { Capital Adequacy }\end{array}$ & $\begin{array}{c}1 \\
-0.024 \\
(0.750)\end{array}$ & 1 & & & \\
\hline Liquidity & $\begin{array}{l}-0.117 \\
(0.117)\end{array}$ & $\begin{array}{l}0.268^{* *} \\
(0.000)\end{array}$ & 1 & & \\
\hline Non-Performing Loan & $\begin{array}{l}-0.290^{* *} \\
(0.000)\end{array}$ & $\begin{array}{c}0.074 \\
(0.323)\end{array}$ & $\begin{array}{l}0.169^{*} \\
(0.023)\end{array}$ & 1 & \\
\hline Operating Expenses & $\begin{array}{l}-0.783^{* *} \\
(0.000)\end{array}$ & $\begin{array}{l}0.164^{*} \\
(0.028) \\
\end{array}$ & $\begin{array}{l}0.366^{* *} \\
(0.000)\end{array}$ & $\begin{array}{l}0.361^{* *} \\
(0.000)\end{array}$ & 1 \\
\hline
\end{tabular}

Note: ${ }^{* *}$ and ${ }^{*}$ show significant correlation at the $1 \%$ and $5 \%$ levels, respectively.

These findings show that the determinants of the banking performance were correlated with each other, providing further signals of the importance of managing these determinants to enhance performances of the banks.

\section{Financial Performance: Conventional}

\section{vs. Islamic Banks}

A panel multiple regression analysis is estimated to measure and analyze the effects of the determinants of the banking performance: capital adequacy, liquidity,non-performing loan/financing, and operating expenses. The estimation of the panel regression model is conducted twice; the first is to measure and analyze the determination of the performance of conventional banks (Equation 1), and the second is to measure and analyze the determinants of the performance of Islamic banks (Equation 2).

Of the three types of panel estimation models, only the common effect model and the fixed effect model were found to be suitable for estimating the data in this study. In contrast, the random effect model cannot be estimated at a smaller number of cross-sections than the number of researched variables. Therefore, the selection of the best model between the common effect 
model and the fixed effect model is tested using a Chow test. The test showed that the fixed effect model is found to be the most suitable model for further data analyses. Table 5 reports the findings of the estimated fixed model.

Table 5

Findings of Determinants of Banking Performance (A Panel Fixed Effect Model)

\begin{tabular}{|c|c|c|c|c|}
\hline Variable & Estimated Coefficient & Standard error & $\mathrm{t}$-Statistic & Probability \\
\hline \multicolumn{5}{|l|}{ Conventional Bank: } \\
\hline Constant & -0.470 & 0.423 & -1.110 & 0.268 \\
\hline Capital Adequacy & $0.089^{* *}$ & 0.017 & 5.179 & 0.000 \\
\hline Liquidity & $0.044^{* *}$ & 0.006 & 7.337 & 0.000 \\
\hline Non-Performing Loan & -0.003 & 0.027 & -0.144 & 0.885 \\
\hline Operating Expenses & $-0.017^{* *}$ & 0.005 & -3.413 & 0.000 \\
\hline \multicolumn{5}{|c|}{ F-Statistics $=67.26 ;$ Probability $(\mathrm{F}-$ Stats $)=0.000 ;$ Durbin-Watson $=0.357 ;$ Adjusted $\mathrm{R}^{2}=0.6895$} \\
\hline \multicolumn{5}{|l|}{ Islamic Bank: } \\
\hline Constant & $12.113^{* *}$ & 0.505 & 20.005 & 0.000 \\
\hline Capital Adequacy & 0.017 & 0.013 & 1.327 & 0.186 \\
\hline Liquidity & $0.005^{*}$ & 0.002 & 2.365 & 0.019 \\
\hline Non-Performing Financing & $0.135^{* *}$ & 0.044 & 3.074 & 0.002 \\
\hline Operating Expenses & $-0.130^{* *}$ & 0.006 & -20.469 & 0.000 \\
\hline
\end{tabular}

As illustrated in Table 5, the study found significant simultaneous effects of capital adequacy, liquidity, nonperforming loan/financing, and operating costs on the performances of both conventional banks and Islamic banks at the $1 \%$ level of significance. The estimated coefficient of determination (Adjusted $\mathrm{R}^{2}$ ) of 0.6895 for the conventional banks signifies that the variations in the banks' performance were explained $68.95 \%$ by the investigated determinants, while the rest $31.05 \%$ is explained by other variables beyond our estimated model, such as good corporate governance, assets management, and other macroeconomic determinants (Chowdhury et al., 2017). Meanwhile, the estimated coefficient determination (Adjusted $\mathrm{R}^{2}$ ) for Islamic banks of 0.7474 indicates that the variations in the banks' performance were explained by $74.74 \%$ of the investigated determinants. In comparison, the rest $25.26 \%$ is explained by other internal and external factors affecting the banking performance that are not included in our estimated model. This finding further shows that the estimated value of Adjusted $\mathrm{R}^{2}$ for Islamic banks is found to be higher than for their conventional counterparts, implying a more 
remarkable ability of determinants to predicts the changes in As illustrated in Table 5, the study found significant simultaneous effects of capital adequacy, liquidity, non-performing loan/financing, and operating costs on the performances of both conventional banks and Islamic banks at the $1 \%$ level of significance. The estimated coefficient of determination (Adjusted $\mathrm{R}^{2}$ ) of 0.6895 for the conventional banks signifies that the variations in the banks' performance were explained 68.95\% by the investigated determinants, while the rest $31.05 \%$ is explained by other variables beyond our estimated model, such as good corporate governance, assets management, and other macroeconomic determinants (Chowdhury et al., 2017).

Meanwhile, the estimated coefficient determination (Adjusted $\mathrm{R}^{2}$ ) for Islamic banks of 0.7474 indicates that the variations in the banks' performance were explained by $74.74 \%$ of the investigated determinants. In comparison, the rest $25.26 \%$ is explained by other internal and external factors affecting the banking performance that are not included in our estimated model. This finding further shows that the estimated value of Adjusted $\mathrm{R}^{2}$ for Islamic banks is found to be higher than for their conventional counterparts, implying a more remarkable ability of determinants to predicts the changes in Islamic banking performance than those in conventional banks.

Furthermore, Table 5 also illustrates that capital adequacy has a significant positive effect on conventional banks' performance at a significant level of $1 \%$. This means that for every $100 \%$ increase in capital adequacy, it has contributed to the rise in the banks' performance by $8.9 \%$, ceteris paribus. This finding is in line with the previous studies conducted by Sukarno \& Syaichu (2006) and Ongore \& Kusa (2013), who found a significant effect of capital adequacy on banking performance.

On the other hand, capital adequacy was found to have an insignificant influence on Islamic banking performances. This indicates that the capital adequacy of Islamic banks was not able to make a real contribution to their performance due to their smaller capital values compared to their conventional counterparts. In other words, any changes in capital adequacy could not be a benchmark for the changes in Islamic banks' performance. This finding is in harmony with previous studies conducted by Dewi (2010) and Sabir \& Habbe (2012), who documented the insignificant effect of capital adequacy on the Islamic banks' performance. 
Moreover, the study recorded a significant positive influence of liquidity on the conventional banks' performance at the $1 \%$ significance level. When the banks could accumulate more funds from the third party (depositors), thus the number of available funds that can be channeled as credit would also increase so that the banks' profit from loan interest would, finally, increase too. Thus, the higher the funds collected by the banks from the depositors, the better would be the performance of the banks. This finding is consistent with the previous studies conducted by Hassan AlTamimi (2010) and Margaretha \& Zai (2013), who found the importance of liquidity in improving banking performance.

A similar effect of liquidity on Islamic banks' performance is also recorded by our study at the $5 \%$ level of significance. This means that for every $100 \%$ increase (decrease) in liquidity, it has led to an increase (a decrease) in the Islamic banking performance by $0.5 \%$, ceteris paribus. Similar to the finding for conventional banks, Islamic banks have proved to be able to channel their funds to productive economic sectors and gain more profits. Thus, the greater the profits generated by the banks, the better their financial performances. These findings support an earlier study by Sabir \& Habbe (2012), who recorded the importance of liquidity on banking performance.

Next, the study documented an insignificant effect of non-performing loans on the performance of conventional banks. This finding shows that banks' credit risk management has been ineffective, thereby contributing an insignificant impact to the banking performance (Chamberlain et al., 2020). This finding is consistent with previous studies that found an insignificant effect of non-performing loans on banking performance (Sukarno \& Syaichu, 2006; Banik \& Das, 2013).

On the other hand, surprisingly, nonperforming financing is found to have a significant positive effect on the performance of Islamic banks at a significance level of $1 \%$. This finding shows that an increase in non-performing financing has contributed to the rise in banking performance, a finding similar to Sabir \& Habbe (2012). This is mainly due to a lower mean value of non-performing financing of the Islamic banks (i.e., 2.61\%) over the study period, which is still within the safer limits of $5 \%$, as determined by the FSA. Thus, any changes in the non-performing financing up to $5 \%$ level would not endanger the Islamic banking financial performance.

Finally, as illustrated in Table 5, a similar significant negative effect of operating costs on the performances were 
found for both conventional and Islamic banks at a significance level of $1 \%$. These findings show that an increase in operating expenses harms banking performances and vice versa. When the operational costs to be borne by the banks are high, then these costs would reduce the net profits and, consequently, lower the banking performances. Conversely, if the banks operated efficiently, the banks would gain a higher profit since the banks worked at the lowest level of expenses. The ability of the management of both conventional and Islamic banks to optimize their operational activities with an efficient level has enhanced performances of the banks. These findings are in accordance with the previous studies that documented a negative effect of operating costs on the performance of conventional banks (Sukarno \& Syaichu, 2006; Margaretha \& Zai, 2013) and performance of the Islamic banks (Wibowo \& Syaichu, 2013).

\section{Implication of the Findings}

The study's findings showed that capital adequacy, liquidity, non-performance loan or financing, and operating expenses simultaneously affected the performances of both conventional and Islamic banks. This finding implies that banks must pay attention to these factors if they intend to improve their financial performances.
Meanwhile, each determinant has a different effect on conventional and Islamic banking performance (Rachdi \& Mokni, 2014). For conventional banks, capital adequacy has a significant positive impact on financial performance, while capital has an insignificant effect on Islamic banks. A larger amount of capital of conventional banks has contributed to improving conventional banking performance. In contrast, capital has an insignificant contribution to enhance Islamic banking performance. Thus, the conventional could further increase its capital to improve its financial performance.

Furthermore, the study documented a similar positive significant effect of liquidity on the performances of conventional banks and Islamic banks. If the banks encounter no liquidity problems, they will gain a higher level of public confidence to transact with them, thereby creating an excellent opportunity for the banks to generate a more profit. The banks must maintain a liquidity level above $85 \%$, as stipulated by the FSA so that they would be able to accomplish their intermediation function properly and continuously improve their performances.

In terms of credit risk management, the conventional banks failed to manage their non-performing loan to enhance their performance, as indicated by the insignificant effect of non-performing loans. 
The conventional banks have an average value of non-performing loans above the $5 \%$ maximum limit determined by the FSA. Meanwhile, Islamic banks have affectively managed financing risk to improve their performance (Chamberlain et al., 2020), as shown by a significant positive effect of non-performing financing on banking performance. During the study period, on average, the amount of non-performing financing was $2.61 \%$, which is below the maximum level set by the FSA. This shows that, if the Islamic banks could manage their non-performing financing to be always below 5\%, their performance would continuously improve. Islamic banks should design a prudent financing policy to ensure non-performing financing at a safe level.

Finally, the study found a similar negative significant effect of operating expenses on the performances of both conventional and Islamic banks. The ability of the banks to manage their operational costs efficiently would ensure an increase in their performances. When the operating expenses incurred by the banks increase, it would adversely affect their net income as well as performance, and vice versa. Thus, this finding implies that banks must manage their operating costs below $92 \%$ to be efficient in their business activities and experience improved performance.

\section{Conclusion}

This study measured and comparatively analyzed the determination of performance between conventional and Islamic banks in Indonesia. The study documented that capital adequacy, liquidity, and operating expenses have significantly influenced the performance of conventional banks, while the non-performing loan has an insignificant effect. Meanwhile, the liquidity, nonperforming loan, and operating expenses were found to significantly determine the performance of Islamic banks, while capital adequacy was recorded to have an insignificant effect on banking performance.

Based on these findings, the study proposes the following recommendations. First, the regulators should ensure the banking institution to abide by their stipulated regulation for the banks to maintain the stability of their performances. Second, the government is advised to support Islamic banks by placing more funds in the Islamic banks to ensure their capital adequacy. Finally, for academicians, this study's findings might be used as a reference for future studies on this topic.

However, to enrich the existing study and produce comprehensive and robust findings on the determinants of banking performance, future studies are suggested to add more banks and consider incorporating both internal and external factors 
determining banking performances in their analysis.

\section{REFERENCES}

Ardiyana, M. (2011). Analisis perbandingan kinerja keuangan bank syari'ah dan bank konvensional sebelum, selama, dan sesudah krisis global tahun 2008 dengan menggunakan metode CAMEL (Studi kasus pada PT Bank Syari'ah Mandiri dan PT Bank Mandiri Tbk). Diponegoro University.

Arfan, M., Basri, H., Handayani, R., Shabri, M. S. A., Fahlevi, H., \& Dianah, A. (2017). Determinants of cash holding of listed manufacturing companies in the Indonesian stock exchange. DLSU Business and Economics Review, 26(2), 1-12.

Aryati, T., \& Balafif, S. (2007). Analisis faktor yang mempengaruhi tingkat kesehatan bank dengan regresi logit. Journal the Winners, 8(2), 111-125.

Banik, B. P., \& Das, P. C. (2013). Comparison of financial performance of state owned commercial banks: A case study of Bangladesh. International Journal of Science and Research, 2(2), 423-428.

Betharino, L. (2015). Analisis perbandingan kinerja keuangan bank konvensional dan bank syariah pada PT. Bank Negara Indonesia Tbk. Artikel Ilmiah Mahasiswa. Universitas Padjajaran.

Chamberlain, T., Hidayat, S., \& Khokhar, A. R. (2020). Credit risk in Islamic banking: Evidence from the GCC. Journal of Islamic Accounting and Business Research, 11(5), 1055-1081. Chowdhury, M. A. F., Haque, M. M., \&
Masih, M. (2017). Re-examining the determinants of Islamic bank performance: New evidence from dynamic GMM, quantile regression, and wavelet coherence approaches. Emerging Markets Finance and Trade, 53(7), 1519-1534.

Dewi, D. (2010). Faktor-faktor yang mempengaruhi profitabilitas bank syariah di Indonesia. Diponegoro University.

Erol, C. F., Baklaci, H., Aydoğan, B., \& Tunç, G. (2014). Performance comparison of Islamic (participation) banks and commercial banks in Turkish banking sector. EuroMed Journal of Business, 9(2), 114-128.

Hamid, A., Majid, M. S. A., \& Khairunnisah, L. (2017). An empirical re-examination of the Islamic banking performance in Indonesia. International Journal of Academic Research in Economics and Management Sciences, 6(2), 219-232.

Hassan Al-Tamimi, H. A. (2010). Factors influencing performance of the UAE Islamic and conventional national banks. Global Journal of Business Research, 4(2), 1-9.

Hassan Al-Tamimi, H. A., Miniaoui, H., \& Elkelish, W. W. (2015). Financial risk and Islamic banks' performance in the Gulf Cooperation Council Countries. The International Journal of Business and Finance Research, 9(5), 103-112.

Hazzi, O. A., \& Kilani, M. I. A. (2013). The financial performance analysis of Islamic and traditional banks: Evidence from Malaysia. European Journal of Economics, Finance and Administrative Sciences, 57, 133-144. Jaffar, M., \& Manarvi, I. (2011). Performance comparison of Islamic 
and conventional banks in Pakistan. Global Journal of Management and Business Research, 11(1), 31-42.

Kassim, S. H., Majid, M. S. A., \& Yusof, R. M. (2009). Impact of monetary policy shocks on the conventional and Islamic banks in a dual banking system: Evidence from Malaysia. Journal of Economic Cooperation and Development, 30(1), 41-58.

Khan, I., Khan, M., \& Tahir, M. (2017). Performance comparison of Islamic and conventional banks: empirical evidence from Pakistan. International Journal of Islamic and Middle Eastern Finance and Management, 10(3), 419433.

Kusumo, Y. A. (2008). Analisis kinerja keuangan Bank Syariah Mandiri periode 2002-2007 (Dengan pendekatan PBI No. 9/1/PBI/2007). $L a$ Riba Jurnal Ekonomi Islam, 2(1), 109131.

Majid, M. S. A., \& Kassim, S. H. (2009). Impact of the 2007 US financial crisis on the emerging equity markets. International Journal of Emerging Markets, 4(4), 341-357.

Majid, M. S. A., \& Kassim, S. H. (2015). Assessing the contribution of Islamic finance to economic growth: Empirical evidence from Malaysia. Journal of Islamic Accounting and Business Research, 6(2), 292-310.

Majid, M. S. A., \& Maulana, H. (2012). A comparative analysis of the productivity of Islamic and conventional mutual funds in Indonesia: Data envelopment analysis (DEA) and general least square (GLS) Approaches. Gadjah Mada International Journal of Business, 14(2), 183-208.
Majid, M. S. A., Musnadi, S., \& Putra, I. Y. (2014). A comparative analysis of the quality of Islamic and conventional banks' asset management in Indonesia. Gadjah Mada International Journal of Business, 6(2), 185-200.

Margaretha, F., \& Zai, M. (2013). Faktorfaktor yang mempengaruhi kinerja keuangan perbankan Indonesia. Jurnal Bisnis Dan Akuntansi, 15(2), 133-141.

Nugraha, D. A. (2014). Analisis perbandingan kinerja keuangan bank syariah dengan bank konvensional (Studi kasus pada PT. Bank Syariah Mandiri dan PT. Bank Central Asia). Universitas Muhammadiyah Surakarta. Ongore, V. O., \& Kusa, G. B. (2013). Determinants of financial performance of commercial banks in Kenya. Issues, International Journal of Economics and Financial, 3(1), 237-252.

Otoritas Jasa Keuangan. (2016). Sharia Banking Statistics.

Pratikto, H., \& Sugianto, I. (2011). Kinerja efisiensi bank syariah sebelum dan sesudah krisis global berdasarkan Data Envelopment Analysis. Jurnal Ekonomi Bisnis, 16(2), 108-117.

Rachdi, H., \& Mokni, R. B. S. (2014). Assessing the bank profitability in the MENA region: A comparative analysis between conventional and Islamic bank. International Journal of Islamic and Middle Eastern Finance and Management, 7(3), 305-332.

Rose, P. S., \& Hudgins, S. C. (2005). Bank Management and Financial Services. McGraw-Hill.

Rosly, S. A., \& Bakar, M. A. A. (2003). Performance of Islamic and mainstream banks in Malaysia. International Journal of Social Economics, 30(12), 1249-1265. 
Sabbina, A. (2014). Analisis perbandingan kinerja keuangan bank syariah selama dan setelah krisis ekonomi global 2008. UIN Syarif Hidayatullah.

Sabir, M. A., \& Habbe, A. H. (2012). Pengaruh rasio kesehatan bank terhadap kinerja keuangan bank umum syariah dan bank konvensional di Indonesia. Jurnal Analisis, 1(1), 79 86.

Setyaningsih, A., \& Utami, S. S. (2013). Analisis perbandingan kinerja keuangan perbankan syariah dengan perbankan konvensional. Ekonomi Dan Kewirausahaan, 3(1), 100-115.

Srisusilawati, P. (2017). Kajian Komunikasi Pemasaran Terpadu Dalam Mendorong Keputusan Pembelian Jasa Perbankan. Amwaluna: Jurnal Ekonomi Dan Keuangan Syariah, 1(1), 1-18. https://doi.org/10.29313/amwaluna.v1i 1.1993

Subaweh, I. (2008). Analisis perbandingan kinerja keuangan bank syariah dan bank konvensional periode 2003-2007. Jurnal Ilmiah Ekonomi Bisnis, 13(2), 112-125.

Sukarno, K. W., \& Syaichu, M. (2006). Analisis faktor-faktor yang mempengaruhi kinerja bank umum di Indonesia. Jurnal Studi Manajemen Organisasi, 3(2), 46-58.

Wasiuzzaman, S., \& Nair Gunasegavan, U. (2013). Comparative study of the performance of Islamic and conventional banks: The case of Malaysia. Humanomics, 29(1), 43-60.

Wibowo, E. S., \& Syaichu, M. (2013). Analisis pengaruh suku bunga, inflasi, CAR, BOPO, NPF terhadap profitabilitas bank syariah. Diponegoro Journal of Management, 2(2), 10-19.

Winarso, B. S. (2008). Perbandingan kinerja keuangan bank syariah sebelum dan pada masa krisis ekonomi: Pendekatan model CAMEL. Logos, 6(1), 20-36.

Yani, R. N., Arfan, M., \& Majid, M. S. A. (2020). What determines Islamic stock returns in Indonesia? Share: Jurnal Ekonomi Dan Keuangan Islam, 9(1), 1-13. 